\title{
Oestrogen Receptor Alpha and Progesterone Receptor in Uterus and Ovaries on Different Days of The Oestrus Cycle in Hyperthyroid Rats
}

\author{
Halil Bozoglu, Turan Karaca* \\ University of Trakya, Faculty of Medicine, Department of Histology-Embryology, Balkan Campus, 22030, Edirne, Turkey
}

\section{A B S T R A C T}

Background: The present study evaluated, in different oestrus cycle phases, the oestrogen receptor alpha $(E R \alpha)$ and progesterone receptor $(\mathrm{PgR})$ in rates with hyperthyroid ovaries and uterus. Materials and Methods: Sixty-four adult female wistar albino rats were used. Animals were randomly separated into eight different groups, four of which constituted the control group and the other four of which were the actual experimental group. Hyperthyroidism was induced by daily s.c. injection of L-thyroxine (L-T4, $250 \mu \mathrm{g} / \mathrm{kg}$ ) for 21 days. Results: Hyperthyroidism induced decreased plasma TSH levels and increased plasma free T4 levels ( $<0.001)$. In addition, it increased plasma oestrogen levels in all cycle phases, and plasma progesterone levels increased in different cycle phases, excluding the oestrus phase, in rats $(P<0.01)$. By the end of the experiment, $\mathrm{ER} \alpha$ percentages were decreased in oestrus days in uterine luminal epithelium; however, ER $\alpha$ percentages were increased in metoestrus phases in hyperthyroid rats. $E R \alpha$ was elevated in proestrus, metoestrus and dioestrus phases in the corpus luteum, and hyperthyroidism also increased $E R \alpha$ percentages in theca folliculi. In uterine luminal epithelium, the hyperthyroidism group showed higher expressions of $P g R(P<0.05)$ in oestrus and metoestrus phases and decreased oestrus phase compared to control rats. Conclusions: As a result, we conclude that both the levels of plasma estrogen and progesterone as well as the differences in the distributions of relevant receptors in ovarian and uterus tissues have an impact on female infertility due to hyperthyroidism.

Key Words: Hyperthyroidism, oestrogen receptor alpha, progesterone receptor, ovary, uterus
Access this article online

Website:

http://nepjol.info/index.php/AJMS

DOI: 10.3126/ajms.v6i4.11816

\section{INTRODUCTION}

Hyperthyroidism can cause malfunctions in many systems. It is the second most common cause of endocrine diseases after diabetes in world. ${ }^{1}$ Hyperthyroidism is often the result of an autoimmune disease with a not clearly detectible cause. It is ten times more common in women than in men. ${ }^{2}$ The main complications of hyperthyroidism are short temper, sleeplessness, exophthalmia, urticaria, vitiligo, myopathy, hepatomegalia, gynaecomastia, decreased fertility, and irregular menses (amenorrhea or polymenorrhea). ${ }^{1,3,4}$ Although both decreased fertility and irregular menses in women with hyperthyroidism have been studied extensively, there are many aspects that have not yet been considered.
Hyperthyroidism causes functional and structural changes in genitalia of humans (ovaries and uterus) as well as in animals. ${ }^{5}$ In women diagnosed with hyperthyroidism, common malfunctions of the ovarian cycle are amenorrhea, oligomenorrhea, and decreased levels of or disappearance of lutein hormone $(\mathrm{LH})$ in the midst of the cycle. ${ }^{6}$

Immunohistochemical staining is the method used to detect the dispersion of ER and $\mathrm{PgR}$ in the human uterus and ovaries during menstrual cycles. ${ }^{7}$ Immunohistochemical staining is also used to show oestrogen and $\mathrm{PgR}$ in ovaries and uteruses of rats. ${ }^{8}$

There are two sub-types of ER: ERß and ER $\alpha$. ERß can be observed in the cell nuclei of granuloza cells as well as 
in primary, secondary and mature follicles. An authentic retention of ERß can be observed in theca cells, luteal cells, germinal epithelium and oocytes and nucleus. A little staining is also observed in atretic follicles or there is no staining at all. $E R \alpha$ is observed in germinal epithelium, interstitial cells and theca cells. ${ }^{9}$

This study aims to demonstrate the change in the distribution of oestrogen and PgR due to the effects of hyperthyroidism in ovarian and uterine tissues of female rats that were infected with hyperthyroidism using L-Thyroxine during different phases of the oestrus cycle.

\section{MATERIAL AND METHODS}

\section{Experimental animals}

Sixty-four mature female Wistar-albino rats with the same biological and physiological features were used for this study. These rats were bred in the Research Department of Experimental Animals in Trakya University, and their weights vary between 200-250 gr. The study was approved by the Institutional Animal Ethical Committee of the Trakya University, Edirne, Turkey (permission number TUHDYEK-2012/02). During this experiment, all subjects were fed with pellet feed (Purina), which contains drinking water and $21 \%$ pure protein in an optimum laboratory atmosphere $\left(22 \pm 1{ }^{\circ} \mathrm{C}, 12\right.$ hour lightness/darkness cycle). Eight groups, four control groups and four experimental groups were formed. At the beginning of the experiment, all subjects were numbered and weighed.

\section{Groups}

Control Groups ( $\mathrm{n}=8$ )

I. Group: Proestrus Control Group

II. Group: Oestrus Control Group

III. Group: Metoestrus Control Group

IV. Group: Dioestrus Control Group

Experimental Groups ( $\mathrm{n}=8) ; 250 \mu \mathrm{g} / \mathrm{kg} /$ day of thyroxin hormone (L-Thyroxine, Sigma) was injected subcutaneously for 21 days

I. Group: Proestrus

II. Group: Oestrus

III. Group: Metoestrus

IV. Group: Dioestrus

\section{Tissue sample collections}

Starting on day 21 of the experiment, a vaginal smear was taken with a moistened swab every 24 hours, after wiping the vulva region with $70 \%$ ethyl alcohol. This smear was then spread on a microscope slide. The smear samples were fixed using 70\% methanol and dried at room temperature. Preparates which were dyed with 1\% Toluidine blue (Sigma-USA) for five minutes were washed with distilled water and dried. Then, they were covered with Canada balsam (Fluka-Germany). The photos of oestrus phase were taken with a CX31 Olympus light microscope and a C-5060 Olympus camera.

After the vaginal smear samples were taken from the experimental and control groups, the rats with the relevant cycles were weighed. After they were intraperitoneally (i.p.) anesthetized with $50 \mathrm{mg} / \mathrm{kg}$ ketamine (Ketalar-Eczacibaş1/ Turkey) and $10 \mathrm{mg} / \mathrm{kg}$ xylazine (Rompun-Bayer/Turkey) and dissected, uterine, ovarian and thyroid samples were taken together and evaluated. These uterine, ovarian and thyroid samples were fixed in a 10\% neutral formaldehyde buffered fixation.

\section{Light microscopic examination}

Uterine, ovarian and thyroid tissues were first fixed in $10 \%$ neutral formaldehyde buffered fixator for 72 hours and then blocked in paraffin. Five $\mu \mathrm{m}$ (micrometre) thick sections were taken from these blocks using Leica RM2245. These sections, taken to demonstrate the histological structural changes in thyroid gland, uterus and ovaries, were stained with Haematoxylin + Eosin $(\mathrm{H}+\mathrm{E})$. They were examined with a light microscope (Olympus CX31-Japan), and the findings were photographed.

\section{Immunohistochemical examination}

At the end of the experiment, the rats were decapitated. Ovarian and uterine tissues were removed, fixed in 10\% neutral formaldehyde buffered solution and, following routine laboratory methods, were embedded in paraffin. Five-micrometre paraffin tissue sections were mounted on poly-L-lysine slides. The slides were air-dried, and the tissue was deparaffinized. The avidin-biotin complex method was used for immunohistochemical staining, as previously reported..$^{10}$ The sections were incubated with a specific monoclonal anti-ER $\alpha$ antibody (1:100; ab37438 Abcam, USA) and an anti-PR (1:40; ab2764-PR-AT 4,14 Abcam, USA). Diaminobenzidine (DAB) was used as a chromogen, and the sections were counterstained with hematoxylin. Ovarian and uterine tissue sections were examined under light microscopy (400), and the number of immunoreactive positive cells were counted in random high-power fields using an Olympus BX51 (Japan) light microscope. Ten serial sections were examined by light microscopy on the preparations obtained from each rat.

\section{Biochemical examination}

TSH $(\mathrm{mIU} / \mathrm{ml})$, Free $\mathrm{T}_{4}(\mathrm{ng} / \mathrm{ml})$ progesterone $(\mathrm{ng} / \mathrm{ml})$ and oestrogen $\mathrm{pg} / \mathrm{ml}$ ) values in the plasma was measured in triplicate using $100 \mu \mathrm{L}$ samples of each plasma with commercially available chemical immunoassay kits (Siemens, Immulite 2000). 


\section{Statistical analysis}

Statistical analysis of variance was carried out using SASv 12.0 package programme. The differences between and among groups were identified using Duncan's test. All data were noted as average $( \pm)$ and standard deviation (SD). In addition, anti-PgR immunoreactive cells were semiquantitatively determined in corpus luteum and granulosa cells in ovarian. Semi-quantitative evaluation of anti-PgR immunoreactive cells density in ovarian is made as follows: none $(-)$, rare $( \pm)$, little $(+)$, medium $(++)$, much $(+++)$, very much $(++++)$.

\section{RESULTS}

Vaginal smear results were present Figure 1.

\section{Body Weights}

The weights of animals in both groups before and after the experiment were evaluated. The weights of the animals in the hyperthyroid group decreased, while the weights of the animals in the control group increased $(\mathrm{P}<0.05$, Table 1$)$.

\section{TSH and Free T4 Levels}

At the end of the experiment, it was found that TSH value in the hyperthyroid group decreased by a statistically significant amount compared to the TSH value of the control group $(\mathrm{P}<0.001$; Table 1$)$. In addition, free $\mathrm{T}_{4}$ levels were higher in the experimental group by a statistically significant amount in comparison to those of the control group $(\mathrm{P}<0.001 ;$ Table 1$)$.

\section{Plasma Oestrogen and Progesterone Levels}

Plasma oestrogen levels were significantly higher in the experimental groups in comparison to the control groups during all menstrual cycle phases $(\mathrm{P}<0.01$ or $\mathrm{P}<0.001$; Table 2). Progesterone levels are statistically lower in proestrus experimental group $(\mathrm{P}<0.01)$ when compared

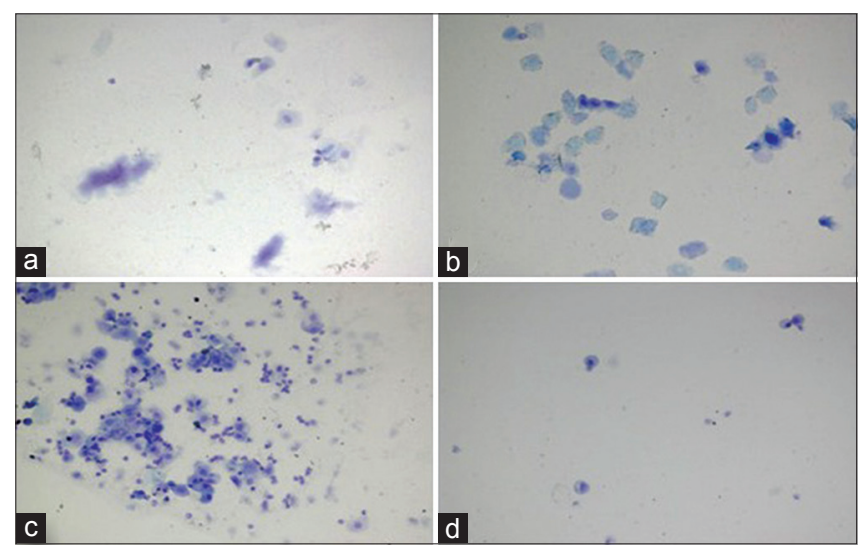

Figure 1: Vaginal smear results. a. Proestrus, b. Oestrus. c. Metoestrus. d. Dioestrus. TB staining, 400X to those of the control group; progesterone values are statistically high in experimental metestrus and diestrus groups when compared to the control groups $(\mathrm{P}<0.001$ and $\mathrm{P}<0.005$, respectively; Table 3 ).

\section{Light Microscopic Findings}

\section{Thyroid gland findings}

Examining the light microscopic findings from H\&E staining sections taken from thyroid tissues of the rats in experimental and control groups revealed normal thyroid follicle structure in the control group. However, the thyroid follicles of the animals in the experimental group were larger than those in the control group. Furthermore, the follicle epithelium was in a flat shape in the experimental group, whereas in the control group, its shape varied between plasmatic and cubic (Figure 2).

Table 1: Body weights and blood TSH and free
$\mathrm{T}_{4}$ levels in the groups
\begin{tabular}{lcc}
\multicolumn{4}{c}{ Control } & Hyperthyroid \\
\hline Blood TSH $(\mathrm{mlU} / \mathrm{ml})$ & $0,051 \pm 0.001$ & $0,004 \pm 0.02^{*}$ \\
Blood free $\mathrm{T}_{4}(\mathrm{ng} / \mathrm{dl})$ & $1,63 \pm 0.4$ & $3,3 \pm 1.2^{*}$ \\
First body weight $(\mathrm{g})$ & $187.3 \pm 12.5$ & $189.8 \pm 14.7$ \\
Final body weight $(\mathrm{g})$ & $192.9 \pm 13.1$ & $171.1 \pm 19.1^{* *}$ \\
$* \mathrm{P}<0.001 ;$ compared with control group, $* * \mathrm{P}<0.05 ;$ compared with first value
\end{tabular}

Table 2: Blood oestrogen levels (pg/ml)

\begin{tabular}{lcc} 
Cycle phases & Control & Hyperthyroid \\
\hline Prooestrus & $67,4 \pm 9.2$ & $79,5 \pm 14.2^{*}$ \\
Oestrus & $46,4 \pm 11.3$ & $57,4 \pm 7.5^{* *}$ \\
Metoestrus & $51,7 \pm 8.4$ & $58,9 \pm 12.4^{*}$ \\
Dioestrus & $44,6 \pm 10.2$ & $57,8 \pm 9.1^{* *}$ \\
\hline$* \mathrm{P}<0.01 ;$ compared with control group, **P<0.001; compared with control group
\end{tabular}

\begin{tabular}{lcc}
\multicolumn{3}{l}{ Table 3: Blood progesterone levels $(\mathrm{ng} / \mathrm{ml})$} \\
\hline Cycle phases & Control & Hyperthyroid \\
\hline Prooestrus & $26,3 \pm 5.6$ & $21,7 \pm 6.4^{*}$ \\
Oestrus & $20,7 \pm 4.8$ & $21,2 \pm 5.1$ \\
Metoestrus & $31,9 \pm 9.3$ & $41,3 \pm 14.3^{* *}$ \\
Dioestrus & $31,7 \pm 11.2$ & $36,4 \pm 8.7^{* * *}$ \\
\hline
\end{tabular}

$* \mathrm{P}<0.01$; compared with control group, $* * \mathrm{P}<0.001$; compared with control group, $* * * P<0.005$; compared with control group

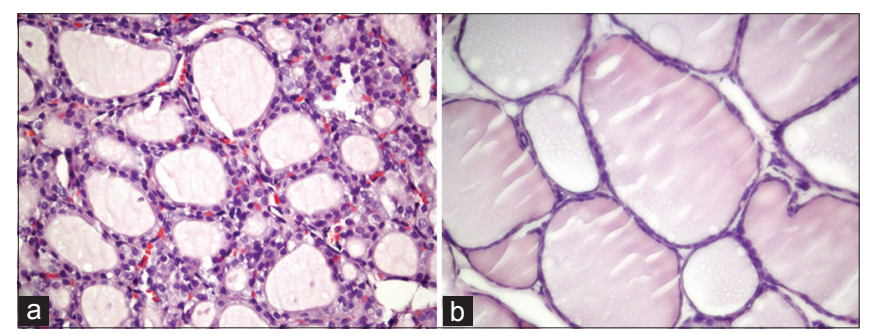

Figure 2: Thyroid histological results. a: In controls, normal thyroid architecture was seen; b: Hyperthyroid group, Hematoxylin \& Eosin, 400X 


\section{Immunohistochemical Findings}

Positively staining cells at eight different sections in four regions, including corpus luteum, germinal epithelium, granulosa cells and theca layer where oestrogen and progesterone were positively staining in the ovary, were counted and noted in per area percentages. Glandular epithelium and stromal cells in both the control and experimental groups were counted in eight different sections and areas, and it was noted in percentages in every cycle during which oestrogen and progesterone were positively staining in the uterus. This examination was conducted by two different researchers independently.

\section{ER Distribution Findings in Uterus}

There was no statistically change in uterine glandular epithelium in proestrus and dioestrus groups between control and experimental groups during immunohistochemical staining $(\mathrm{P}>0.05)$. The number of $\mathrm{ER} \alpha$ decreased in the rats in the experimental group with a statistical significance when compared to the control group ( $\mathrm{P}<0.05)$. In addition, during the metoestrus phase, glandular epithelium in the experimental group increased with a statistical significance when compared to the control group ( $<0.01$; Figure 3a, b; Figure 4).

The number of ER $\alpha$-positively stromal cells in oestrus phase decreased in the experimental group with a statistical significance when compared to the control group in uterus $(\mathrm{P}<0.005$ Figure 5$)$. There were no statistically significant differences between the experimental and control groups during other stages of the oestrus cycle $(\mathrm{P}>0.05$; Figure 5).

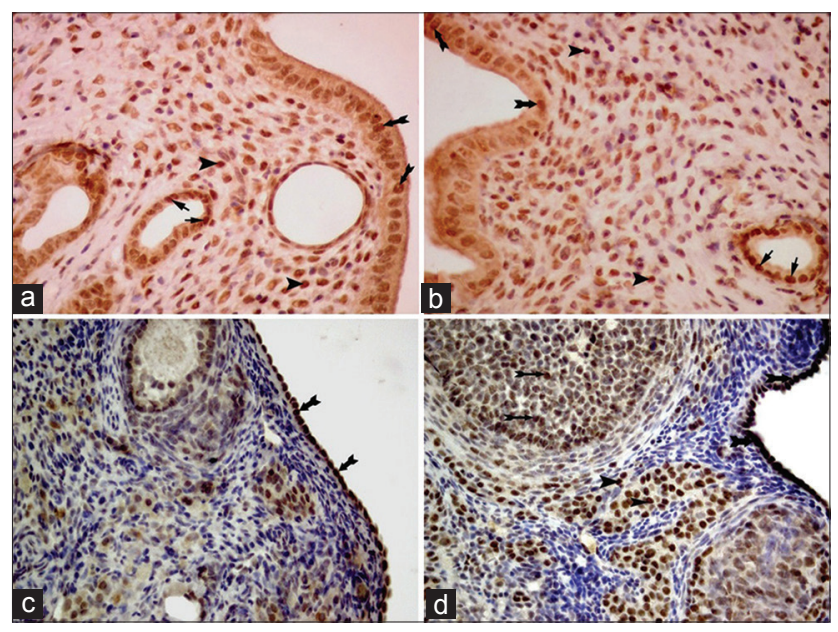

Figure 3: Uterine and ovarian histological ER $\alpha$ results: (a) Control uterus (Oestrus); b: Hyperthyroid uterus (Proestrus). ER $\alpha$-positive epithelial cells (thick arrow), ER $\alpha$-positive stromal cells (arrowhead), ER $\alpha$-positive glandular epithelial cells (thin arrow). c: Control ovarian (Proestrus); d: Hyperthyroid ovarian (dioestrus); 400X, ER $\alpha$-positive germinal epithelial cells (thick arrow), ER $\alpha$-positive ovarian stromal cells (arrowhead), ER $\alpha$-positive cells granulosa cell (thin arrow). Immunoperoxidase, Hematoxylin counterstain, 400X.

\section{ER Distribution Findings in Ovarian}

$\mathrm{ER} \alpha$ was statistically increased in all cycle phases in the experimental groups, excluding oestrus, compared to the control groups at corpus luteum $(\mathrm{P}<0.05$; $\mathrm{P}<0.01$; Figures 6). The ovarian germinal epithelium of the control group and the experimental group were very close together, as were almost all stained oestrogen-positive cells. Phases of menstrual cycle ovarian granulosa cells in the experimental groups compared to those of the control groups did not differ significantly. In the proestrus and metoestrus phases, theca follicle ER $\alpha$ positive cell numbers increased significantly in the experimental groups compared to the control groups $(\mathrm{P}<0.05$; Figure 7 ).

\section{PgR Distribution Findings in Uterus}

PgR immunohistochemical staining revealed a statistically significant decrease in the number of $\mathrm{PgR}$ in uterine lumen and glandular epithelium cells during the proestrus phase of the menstrual cycle in the experimental group when compared to that of the control group. Additionally, during oestrus and metoestrus phases, there was a statistically significant increase in the experimental groups when compared to the control groups (respectively; $\mathrm{P}<0.001$ and

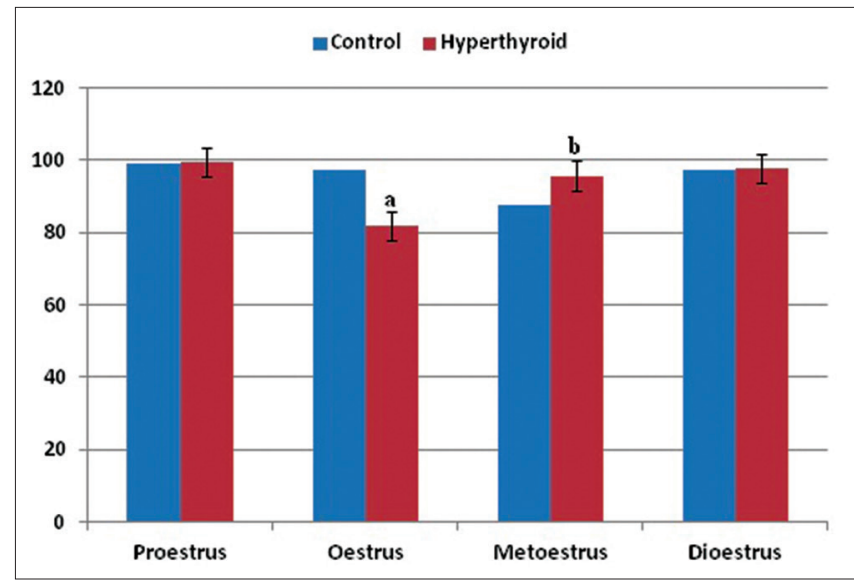

Figure 4: Uterine glandular epithelium cells percentages $\mathrm{ER} \alpha$. a: $\mathrm{P}<0.005$; compared to control group; $\mathrm{b}: \mathrm{P}<0.01$; compared to control group

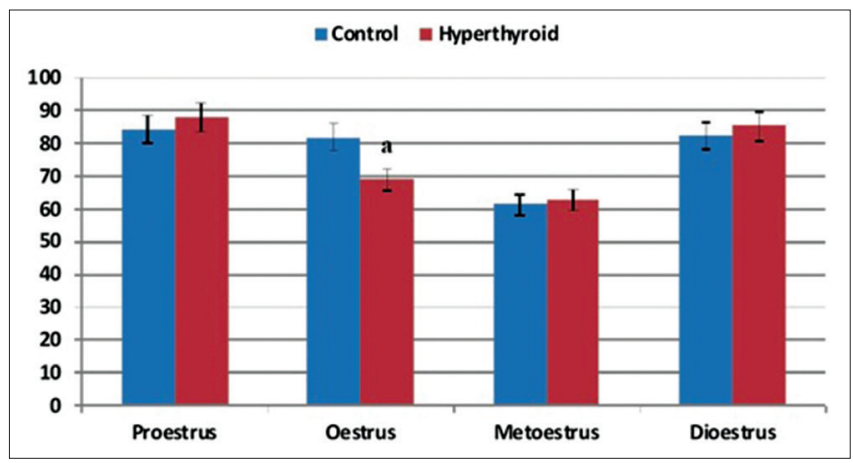

Figure 5: Percentage of ER $\alpha$-positive cells in uterine stromal cells. a: $\mathrm{P}<0.005$; compared to control group. 
$\mathrm{P}<0.005)$. There was no difference between experimental and control groups during the dioestrus phase $(\mathrm{P}>0.05$; Figure 8a,b; 9).

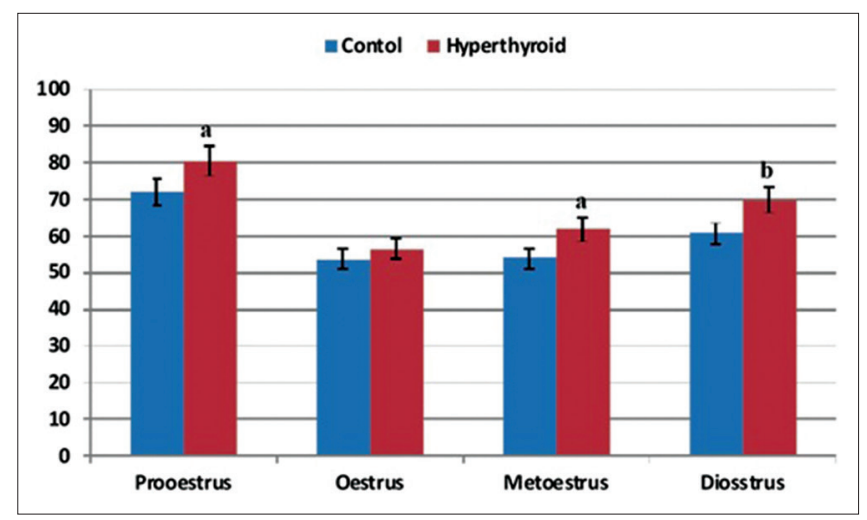

Figure 6: Distribution of percentages of corpus luteum of the ER. a: $\mathrm{P}<$ 0.05; compared to control group; b: $\mathrm{P}<0.01$; compared to control group.

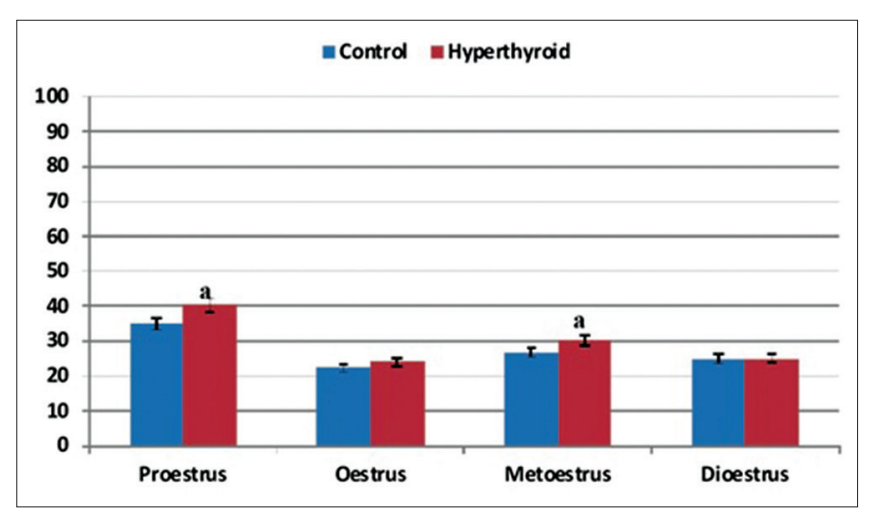

Figure 7: ER $\alpha$-positive cells in ovarian theca layer percentages. a: $\mathrm{P}<0.05$; compared to control group.

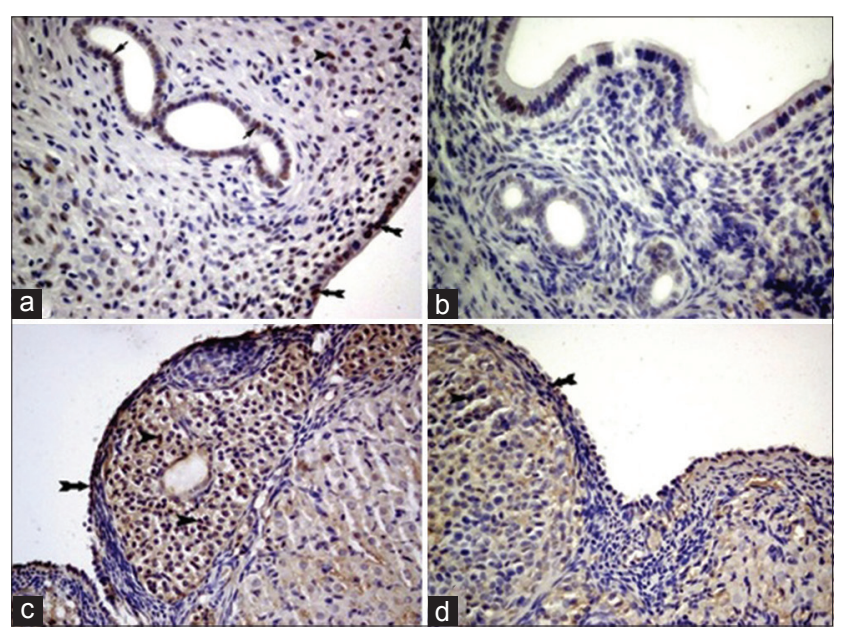

Figure 8: Uterus and ovarian histological PgR results. a: Control uterus (Diestrus); 400X. b: Hyperthyroid metestrus uterus. c: Hyperthyroid metestrus ovary d: Control ovary. PgR-positive stromal cells (arrowhead), PgR-positive epithelium cells (thick arrow), PgR-positive glandular epithelium (thin arrow). Immunoperoxidase, Hematoxylin counterstain, $400 \mathrm{X}$

\section{PgR Distribution Findings in Ovarian}

Although there is an increase in the experimental group when compared to the control group in all phases of the cycle PgR immunoreactive of ovarian germinal epithelium, this increase is at a statistically significant level during the oestrus, metoestrus $(\mathrm{P}<0.05)$ and dioestrus $(\mathrm{P}<0.005)$ phases (Figure 8c,d; 10). Table 4 shows semi-quantitative evaluation results of corpus luteum and granulosa cells immunoreactive of $\mathrm{PgR}$ in ovarian.

\section{Table 4: Distribution of PgR-immunopositive cells in corpus luteum and granulosa cells}

\begin{tabular}{lcc} 
Group and phase & Corpus luteum* & Granulosa cells \\
\hline Control proestrus & - & \pm \\
HT proestrus & \pm & + \\
Control oestrus & - & - \\
HT oestrus & \pm & \pm \\
Control metoestrus & - & + \\
HT metoestrus & \pm & ++ \\
Control dioestrus & \pm & - \\
HT dioestrus & + & -
\end{tabular}

HT: Hyperthyroid; *: None $(-)$, rare $( \pm)$, little (+), medium (++), much (+++), very much (++++)

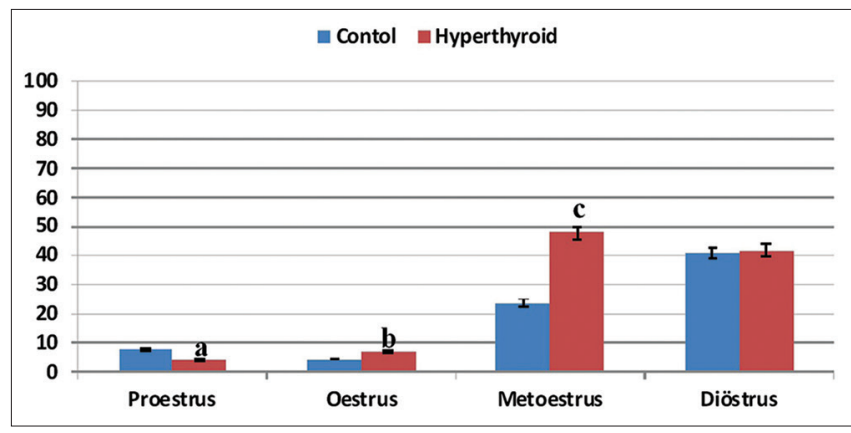

Figure 9: Distribution of percentages in the uterine gland epithelial cells of PgR. a: $\mathrm{P}<0.001$; compared to control group; $\mathrm{b}$ : $\mathrm{P}<0.005$; compared to control group; c: $\mathrm{P}<0.001$; compared to control group.

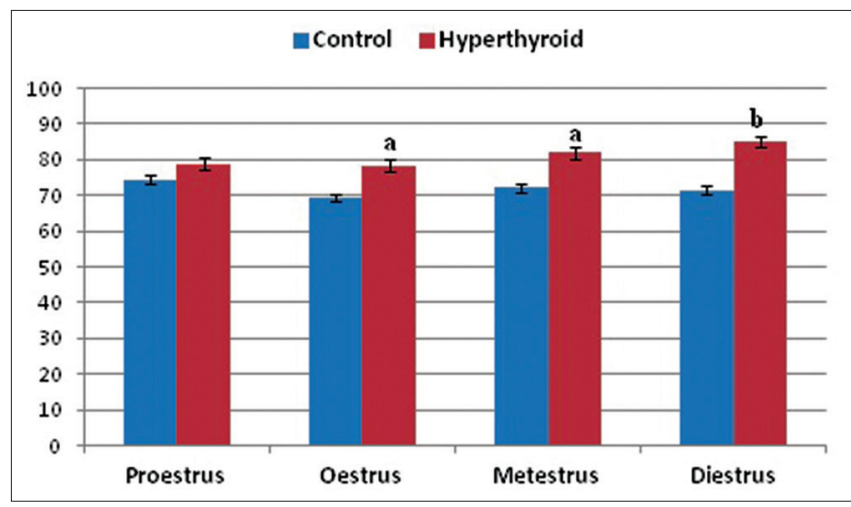

Figure 10: Distribution of percentages in the ovarian germinal epithelial cells of PgR. a: $\mathrm{P}<0.05$; compared to control group; b: $\mathrm{P}<0.005$; compared to control group. 


\section{DISCUSSION}

Thyrotoxicosis is a syndrome caused by an excess of free thyroid hormones, with multiple etiologies and manifestations, which can affect all body systems. ${ }^{11}$ The causes of illnesses include hyperthyroidism and thyrotoxicosis with low levels of radioactive uptake. The most common causes of hyperthyroidism are BasedowGraves disease, toxic multinodular goitre and toxic adenoma.

Many studies indicate that TSH which is among free $\mathrm{T}_{3}$ and free $\mathrm{T}_{4}$ blood plasma concentrations and TSH which is used to identify the clinical table of hyperthyroidism are unusually low, and free $T_{3}$ and free $T_{4}$ are above usual limits. The study on rats by Ozguner et al. demonstrates that TSH levels are statistically lower when compared to the control group, and free $\mathrm{T}_{4}$ values are statistically higher when compared to the control group. ${ }^{12}$ These findings are similar to this study's findings.

High blood thyroid hormone concentrations in patients with hyperthyroidism affect different organs and systems; therefore, findings and symptoms from the affected organs and tissues are observed. ${ }^{13}$ Thyroid hormones can affect many systems in patients, such as reproductive functions. ${ }^{12}$ It is debated whether these functions are a direct result of its effect on reproductive organs or its effect on the hypophysis axis.

Hyperthyroidism causes infertility in genital systems either directly, through the organs' own receptors, or indirectly, through the hypophysis axis. Studies on the effects of hyperthyroidism on infertility usually include not only its effects on the menstrual cycle but also its effects during pregnancy. High doses of thyroxin in neonatal rats causes delays in vaginal widening and the first oestrus. ${ }^{14}$ Thyrotoxicosis before puberty can delay sexual maturity and the first menstrual cycle. ${ }^{6}$ Similarly, menarche age of females with thyrotoxicosis is higher when compared to individuals with no endocrine disease. ${ }^{15}$

Although ovulatory menstrual cycles occur in women with thyrotoxicosis, menstrual disturbances are common. For this reason, when women with thyrotoxicosis do not have regular menstrual period, pregnancy should be considered. The most common anomalism is oligomenorrhea, and oligomenorrhea can turn into amenorrhea. ${ }^{6}$ This situation is first indicated in a classic study by Von Bassedow. ${ }^{16}$ Polymenorrhea is less common than hyperthyroidism. The frequency of these menstrual disturbances varies widely. In another study, Joshi et al. indicate that $64.7 \%$ of all women with hyperthyroidism suffer from menstrual irregularities, and $17 \%$ of them do not have any diseases. ${ }^{17}$
In an experimental study, De Moraes et al. found that the plasma value of progesterone hormone is high before oestrus, whereas its value becomes almost normal after oestrus. ${ }^{18}$ In this current study, plasma progesterone values of the control group during the phases of the menstrual cycle are parallel with the previous studies on rats. ${ }^{9,19}$ Plasma progesterone levels are low in the group with hyperthyroidism during proestrus phase of the cycle when compared to the levels of the control group. However, these levels are almost the same as those in the control group during oestrus phase, while they are statistically high during metoestrus and dioestrus phases.

Similar to the studies by Jacobs et al. (1980) and Kudolo et al. (1984), the existence of $\mathrm{ER} \alpha$ ve PgR distributions in ovarian was observed in germinal epithelium, granulosa cells, corpus luteum and connective tissue between follicles in different rates during menstrual cycle in our study. 20,21 This finding was evaluated as proof that steroid hormones can have regulatory effects on follicle development through their receptors, and at the same time hyperthyroidism affects ER $\alpha$ and PgR localisation.

In immunohistochemical studies related to $\mathrm{ER} \alpha$ and $\mathrm{PgR}$ distribution in uterus, the existence of receptors was detected in epithelium cells, connective tissue cells and smooth muscle cells. The existence of receptors was also observed in endothelium cells, perivascular connective tissue cells and blood cells. ${ }^{22}$

This current study finds that the localisation of oestrogen and $\mathrm{PgR}$ in uterus differs according to the phases of the menstrual cycle. In the experimental group with hyperthyroidism, $E R \alpha$ ve $P g R$ distribution in stromal cells and glandular epithelium differs according to the phases of the menstrual cycle when compared to the control group.

Previous studies have demonstrated that the oestrogen hormone in epithelial cells and uterine stroma affects the expression of oestrogen and PgRs. Moreover, some studies show that high follicular oestrogen levels can be parallel with high levels of oestrogen and PgRs. ${ }^{23}$ Another study indicates that while oestrogen increases its own receptors and $\mathrm{PgRs}$, progesterone can decrease not only its own level but also ER levels. ${ }^{24}$

In the semi-quantitative evaluation of $\mathrm{PgR}$ in ovarian, it has been observed that PgRs in corpus luteum of control groups are negative during proestrus, oestrus and metoestrus phases. In addition, their levels are highest during the dioestrus phase in the group with hyperthyroidism. In the immunohistochemical evaluation, PgRs in granulosa cells are negative during oestrus and dioestrus phases in the control group, during dioestrus phase in the group with hyperthyroidism (Table 4). 


\section{CONCLUSION}

In this current study, ER $\alpha$ is detected in varying proportions, depending on the menstrual phases, in ovarian tissue of the control and experimental groups. Its uptake is observed in germinal epithelium, theca cells, granulosa cells and corpus luteum, while there is a partial uptake in antrum. There is a statistically significant increase in the receptor numbers in theca cells and corpus luteum during the phases of the menstrual cycle in the group with hyperthyroidism when compared to the control group. There is no statistically significant increase in germinal epithelium and granulosa cells. The increase in $E R \alpha$ in different regions of ovarian in the experimental group is assessed as a result of the increase in the receptor concentration of oestrogen plasma concentration. These result in irregularities in the menstrual cycle, due to changes in the number of $\mathrm{ER} \alpha$ and $\mathrm{PgR}$ as hyperthyroidism, which have been shown to be an important factor in infertility.

\section{ACKNOWLEDGEMENTS}

This work was supported by grant number 2012/140 from the Trakya University Research Fund, Edirne, Turkey.

\section{REFERENCES}

1. Özata M. (Turkish) Tiroid hastalıkları tanı ve tedavisi. Ankara GATA Basımevi; 2003; 42-78.

2. Fauci AS, Kasper DL, Hauser SL, Longo Dan L, James $\mathrm{J}$ and Harrison L. Principles of Internal Medicine. Volume 2: $15^{\text {th }}$ ed. North America; Mc Graw -Hill Componies, 2001; 2060 - 2078.

3. Gordon GG and Southren AL. Thyroid-hormone effects on steroid-hormone metabolism. Bulletin New York Academy of Medeicine 1977; 53:241-259.

4. Yamazaki K, Sato K, Shizume K, Kanaji Y, Ito Y, Obara T, et al. Potent thyrotropic activity of human chorionic gonadotropin variants in terms of $125 \mathrm{I}$ incorporation and de novo synthesized thyroid hormone release in human thyroid follicles. The Journal of clinical endocrinology and metabolism 1995; 80:473-479.

5. Maruo T, Hiramatsu S, Otani T, Hayashi M and Mochizuki M. Increase in the expression of thyroid hormone receptors in porcine granulosa cells early in follicular maturation. Acta Endocrinologica 1992; 127:152-160.

6. Thomas $\mathrm{R}$ and Reid RL. Thyroid disease and reproductive dysfunction: a review. Obstetrics and Gynecology 1987; 70: 789798.

7. Thijssen JHH. Progesterone receptors in the human uterus and their possible role in parturition. The Journal of Steroid Biochemistry and Molecular Biology 2005; 97: 397-400.

8. AksoyA. (Turkish) Yaşlanmaya Koşut Sıçan Ovaryum'unda Folikül İnce Yapısı ve Folikül Uyaran Hormon Reseptörlerinin (FSHR), Östrojen Reseptörlerinin(ER), Progesteron Reseptörlerinin (PR)
İmmünohistokimyasal Olarak Belirlenmesi (Tez). Ankara: Gazi Üniv Sağlık Bilimleri Enst Histoloji ve Emb ABD; 2008.

9. Rose MP, Gaines Das RE and Balen AH. Definition and measurement of follicle stimulating hormone. Endocrine Reviews 2000; 21: 5-22.

10. Lin SL, Tu BB, Du XG, Yan LY and Qiao J. Lower expression of ER- $\alpha 36$ is associated with the development of endometrial hyperplasia in PCOS patients. Histology and Histopathology 2013; 28(11):1491-1498.

11. Mittra ES, Niederkohr RD, Rodriguez C, El-Maghraby T and McDougall IR. Uncommon causes of thyrotoxicosis. The Journal of Nuclear Medicine 2008; 49: 265-278.

12. Özgüner $M$, Altuğ Ş, Ural $M$ and İşler M. (Turkish) Deneysel hipertiroidinin erişkin sıçan testis dokusunda oluşturduğu histolojik değişiklikler Süleyman Demirel Üniversitesi Tıp Fakültesi Dergisi 2004; 11(3): 1-6.

13. Doufas $A G$ and Mastorakos G. The hypothalamic pituitary thyroid axis and the female reproductive system. Endocrine Unit Evgenidion Hospital University of Athens Medical School, Athens, Greece. 2000; 900: 65-76.

14. Gellert RJ, Bakke JL and Lawrence NL. Delayed vaginal opening in the rat following pharmacologic doses of T4 administered during the neonatal period. The Journal of Laboratory and Clinical Medicine 1971; 77: 410-416.

15. Mastorakos GNS, MitsiadesAG, Doufas AG and Koutras DA. Hyperthyroidism in McCune-Albright syndrome with a review of thyroid abnormalities sixty years after the first report. Thyroid 1997; 7: 433-439.

16. Von Basedov CA. Exophthalmos durch hypertrophie des Zellgewebes in der. Augenhohl Wochenschrift Heilk 1840; 6: 197.

17. Joshi JV, Bhandarkar SD, Chadha M, Balaiah D and Shah R. Menstrual irregularities and lactation failure may precede thyroid dysfunction of goitre. Journal of Postgraduate Medicine1993; 39: 137-141.

18. Moraes GVD, Vera-Avila HR, Lewis AW, Koch JW, Neuendorff DA and Hallford DM. Influence of hypo- or hyperthyroidism on ovarian function in Brahman cows. Journal of Animal Science1998; 76: 871-879.

19. Hubscher $\mathrm{CH}$, Brooks $\mathrm{DL}$ and Johnson JR. A quantitative method for assessing stages of the rat estrous cycle. Biotechnic \& Histochemistry 2005; 80(2): 79-87.

20. Jacobs BR, Suchocki $S$ and Smith RG. Evidence for a human ovarian progesterone receptor. American Journal of Obstetrics and Gynecology 1980; 138: 332-336.

21. Kudolo GB, Elder MG and Myatt L. A novel oestrogen-binding species in rat granulosa cells. The Journal of Endocrinology 1984; 102: 83-91.

22. Press MF, Nausek-GaulbI NA and Greene GL. Estrojen receptor localization in the female genital tract. The American Journal of Pathology 1986; 123: 280-291.

23. Kurita T, Lee K, Cooke PS, Taylor JA, Lubahn DB and Cunha GR. Paracrine regulation of epithelial progesterone receptor by estradiol in the mouse female reproductive tract. Biology of Reproduction 2000; 62: 821-830.

24. Snijders MP, de Goeij AF, Debets-Te Baerts MJ, Rousch MJ, Koudstaal J and Bosman FT. Immunohistochemical analysis of oestrojen receptors and progesterone receptors in the human uterus throughout the menstrual cycle and after the menopause. Journal of Reproduction and Fertility1992; 94: 363-368. 